University of Wollongong

Research Online

Faculty of Arts, Social Sciences and Humanities

- Papers

Faculty of Arts, Social Sciences \& Humanities

2020

Situating financialisation in the geographies of neoliberal housing

restructuring: reflections from Ireland and Australia

Cian O'Callaghan

Pauline M. McGuirk

University of Wollongong, pmcguirk@uow.edu.au

Follow this and additional works at: https://ro.uow.edu.au/asshpapers

Research Online is the open access institutional repository for the University of Wollongong. For further information contact the UOW Library: research-pubs@uow.edu.au 


\title{
Situating financialisation in the geographies of neoliberal housing restructuring: reflections from Ireland and Australia
}

\author{
Abstract \\ The growing literature on housing financialisation offers an increasingly fine-grained analysis of how \\ financial actors shape housing markets and systems internationally. Nevertheless, a lack of clarity \\ remains about the geographical and temporally specific ways that financialisation grafts onto and \\ amplifies wider neoliberal housing restructuring, as well as the role the global financial crisis (GFC) plays \\ in its variegated trajectories. In this paper, we address this problematic by situating housing \\ financialisation within the context of longer-term neoliberal restructuring via a comparative analysis of \\ Ireland and Australia. Our empirical and conceptual aims are two-fold. First, we deploy our comparison to \\ disentangle housing financialisation from wider processes of neoliberal restructuring and identify the \\ moments in which financialisation acts as a crucial accelerant that amplifies but also mutates extant path \\ dependent trajectories. Second we mobilise comparison to reflect critically on the role that crisis and \\ crisis discourses play in facilitating regulatory restructuring through financialised logics. While in Ireland \\ the crash formed a juncture for regulatory capture by financial actors and the deepening of \\ financialisation as a core component of housing, Australia's response to the GFC was a reassertion of the \\ neoliberal status-quo. However, we contend that Australia's housing markets are now characterised by \\ many aspects of financialisation and remain vulnerable to its impacts. We argue that comparative \\ analysis allows us to view the path dependent nature of neoliberal restructuring as well as the variegated \\ geographies and temporalities of financialisation on housing regimes internationally.

\section{Publication Details} \\ O'Callaghan, C. \& McGuirk, P. (2020). Situating financialisation in the geographies of neoliberal housing \\ restructuring: reflections from Ireland and Australia. Environment and Planning A.
}

This journal article is available at Research Online: https://ro.uow.edu.au/asshpapers/381 


\title{
Situating financialisation in the geographies of neoliberal housing restructuring: reflections from Ireland and Australia
}

\author{
Cian O'Callaghan, School of Natural Sciences, Trinity College Dublin \\ Pauline M`cuirk, School of Geography and Sustainable Communities, University of \\ Wollongong
}

Published in Environment and Planning C

DOI: $10.1177 / 0308518 \times 20961791$

\begin{abstract}
The growing literature on housing finacialisation offers an increasingly fine-grained analysis of how financial actors shape housing markets and systems internationally. Nevertheless, a lack of clarity remains about the geographical and temporally specific ways that financialisation grafts onto and amplifies wider neoliberal housing restructuring, as well as the role the global financial crisis (GFC) plays in its variegated trajectories. In this paper, we address this problematic by situating housing fincialisation within the context of longerterm neoliberal restructuring via a comparative analysis of Ireland and Australia. Our empirical and conceptual aims are two-fold. First, we deploy our comparison to disentangle housing financialisation from wider processes of neoliberal restructuring and identify the moments in which financialisation acts as a crucial accelerant that amplifies but also mutates extant path dependent trajectories. Second we mobilise comparison to reflect critically on the role that crisis and crisis discourses play in facilitating regulatory restructuring through financialised logics. While in Ireland the crash formed a juncture for regulatory capture by financial actors and the deepening of financialisation as a core component of housing, Australia's response to the GFC was a reassertion of the neoliberal status-quo. However, we contend that Australia's housing markets are now characterised by many aspects of financialisation and remain vulnerable to its impacts. We argue that comparative analysis allows us to view the path dependent nature of neoliberal restructuring as well as the variegated geographies and temporalities of financialisation on housing regimes internationally.
\end{abstract}

Key words: housing financialisation; neoliberalisation; crisis; Ireland; Australia 


\section{Introduction}

Housing literature informed by critical political economy has pointed to the emergence of a set of global conditions associated with the financialisation of housing (Madden and Marcuse, 2016), while housing forms a backbone to contemporary understandings of financialisation (Aalbers, 2016). Scholarly analyses have characterised housing financialisation prior to the global financial crisis (GFC) as focused on capital switching into property and mortgage markets and the expansion of secondary mortgage markets (Christophers, 2014); while, following the GFC, these processes were consolidated through financial actors "capitalising" on the crisis (Waldron, 2018) by buying up distressed assets, pushing new regulatory and policy instruments, and extending a new "frontier" of financialisation into rental housing (Fields, 2018). Housing researchers have claimed that, cumulatively, these shifts have resulted in global trends of price escalation, unaffordability, declining ownership, rising rental costs, homelessness and, in the Global North, a concomitant residualisation of social housing (Aalbers, 2015).

Nevertheless, there are ongoing debates about the utility and limits of the concept of financialisation itself (Christophers, 2015a). In large part due to its centrality to understandings of the 2008 GFC, financialisation has been linked to and often made indistinguishable from neoliberalisation and globalisation. By foregrounding the financialisation of mortgage markets as the cause of the crisis (particularly via the mortgagedebt crisis), rather than as one key component of a more general and longer-term set of shifts, research obscured the interplay between the deployment of mechanisms of financial engineering and long-term neoliberal restructuring of housing systems. Nonetheless, more recent finer-grained work has shed light on this interplay (see Aalbers, 2019a for an overview). Recent empirical work on financialisation adds greater precision to the concept in at least two respects. First, it identifies and elaborates the specific mechanisms, technologies and practices through which different housing sectors are made more financialised (Fields, 2018). Second, it emphasises the role of the State in facilitating or mediating processes and practices of financialisation (Beswick and Penny, 2018; Ward and Swyngedouw, 2018). Thus a clearer picture has begun to emerge of the ways that financial actors seek to shape the regulatory and institutional structures of housing markets and systems within and across particular historical moments.

In line with this research trajectory, we seek to situate financialisation - understood as a set of mechanisms, practices and technologies - within the context of longer-term neoliberal state restructuring of housing and to parse its geographically and temporally contingent unfolding. We do so through a comparative analysis of the restructuring of housing in two very different contexts - Ireland and Australia-both of which are characterised by neoliberalisation and largely converge on the global housing conditions asserted in the literature. Both nations' housing systems are characterised by the dominance of (debtbased) homeownership, social housing residualisation, and the emergence of "generation 
rent" (Maalsen, 2018) Yet important differences exist in terms of housing policy systems, the texture of neoliberalisation and, significantly, exposure and responses to the GFC. Via a comparative analysis that broadly traces geographically and temporally differentiated processes of financialisation through longer-term shifts in housing systems, the GFC and its aftermath, we suggest that systemic similarities in the trajectories of housing financialisating are emergent across both countries.

In positioning our analysis of the variageted dynamics of housing systems in terms of the relationship between neoliberalisaing policy path dependencies and the critical juncture of the GFC, our empirical and conceptual aims are two-fold. First, we deploy our comparison to highlight how processes and practices of financialisation are contingently layered onto (but also transform) the shifting contours of the neoliberal state. In doing so, we disentangle housing financialisation from wider processes of neoliberal restructuring and identify the moments in which financialisation acts as a crucial accelerant that amplifies but also mutates extant path dependent trajectories. In line with moves in the financialisation literature away from big picture narratives of transformations in late capitalism and towards understandings of the role of specific practices in the property-finance nexus, we contend that the GFC is an important heuristic in apprehending points of transformation, but only if we can begin to tease out housing financialisation as a contingent outcome of longer-term neoliberal restructuring. Second we mobilise comparison to reflect critically on the role that crisis and crisis discourses can play in facilitating regulatory restructuring through financialised logics, resulting in amplification and intensification of the financialisation process. In doing so, we redress the sense in which the centrality of 'crisis' in conceptual and empirical investigations of financialisation and its geographical impacts has contributed to a lack of definition around the situated and differentiated workings of financialization in transforming housing systems over the longer term.

Methodologically, we draw primarily on desk-top analysis via systems embedded research aimed to "identify the dynamic between policy and institutions including the market; and the interaction between the housing system and wider socio-economic institutions..." (Stephens 2011: 353). We combine reviews in Ireland and Australia of housing scholarship, grey literature and secondary sources across the housing and financial fields, combined with contemporaneous media analysis of mainstream and more specialised media. We developed comparative tables to trace key policy trends and the parameters that have shaped the contingent configuration of common trajectories in each context. We used these to pinpoint key dimensions of common trajectories and differentiation, structuring our analysis broadly around pre- and post-crisis tendencies and their relationship to financialisation.

The paper proceeds as follows. First, we outline the literature on housing financialisation, paying particular attention to two conceptual questions: the relationship between 
theorisations of financialisation and neoliberal restructuring and the neoliberalised state, and the empirical and conceptual role of 'crisis' in mediating understandings. We then offer an overview of the restructuring of housing systems in Ireland and Australia up until the GFC, before detailing the divergent responses of these countries to the GFC, in particular identifying the points at which housing financialisation has been deepened or anticipated. In conclusion, we offer an analysis of the interplay between housing financialisation, the neoliberal state and the juncture of crisis and 'crisis-talk' across both cases.

\section{Housing (financialisation) and the neoliberalised state}

Financialisation has claimed to offer an explanatory framework for understanding restructuring relationships between states, markets, and society in late capitalism. The concept provides a new thread (the growing power of finance capital and financial logics) layered onto established narratives previously captured under the banner of neoliberalisation or globalisation (Peck, 2010). As defined by Aalbers $(2017,3)$, financialisation refers to "the increasing dominance of financial actors, markets, practices, measurements and narratives, at various scales, resulting in a structural transformation of economies, firms (including financial institutions), states and households". Others, however, find the concept theoretically imprecise (Christophers, 2015a) and lacking distinction from wider neoliberal restructuring. Perhaps inevitably, the "the onset of the global financial crisis" (ibid, 184, emphasis in original) triggered an explosion of scholarly attention on financialisation. The GFC was a lightening-rod both as the apotheosis of a particular narrative trajectory of the financialisation of capitalism and as a conceptual lens through which to understand the significance of housing in the collapse of the global economy. Yet this has instituted a sort of circular reasoning whereby "sometimes financialisation is the explanandum (the phenomenon to be explained), sometimes the explanans (the thing that explains) and sometimes as a mechanism intervening between causes and consequences" Aalbers $(2016,2)$.

Debates on financialisation have been keenly aware of this dilemma, perhaps nowhere moreso than with regard to housing financialisation. As such, literature on housing financialisation sits at the intersection between explanations of macro-level shifts in capitalism and more specialist accounts of how dynamic intersections between housing, real-estate and rentier capitalism are instrumental in restructuring cities, welfare regimes and households. Many commentators locate the root cause of the global housing crisis in the growing commodification of housing (Madden and Marcuse, 2016), in turn viewed as an outcome of financialisation. However, these accounts are often characterised by a lack of conceptual distinction between financialisation as a specific mode of treating housing provision, and the restructuring of the central role of housing in state welfare systems under neoliberalism. In the wake of the GFC, a set of studies have sought to explain secondary mortgage market dynamics as a trigger for the credit crunch and the collapse of financial insitutions (Christophers, 2015b). In explicating these dynamics, however, the narrative 
inevitably becomes entangled in more nebulous, longer-term processes of restructuring at a range of scales. As such, this work treated housing financialisation in terms of broader transformations of the capitalist system from the 1970s, in particular the transition to neoliberalism, wherein capitalism's inherent overaccumulation 'crises' have been addressed via financial engineering's facilitation of 'capital switching' to the secondary circuit (Christophers, 2011). Following Harvey (2010), this work emphasised how neoliberalism's impact on wage stagnation was temporarily solved by the expansion of credit, notably mortgage-credit, to middle- and working-class households. Coupled with this is the expansion and qualitative transformation of capital switching into built environments (Christophers, 2011) with the problem of real estate's illiquidity and spatial fixity being overcome by financial engineering through which real estate has transformed from spatially fixed into a transferable financial asset (Aalbers, 2016). However, questions abound about whether the restructuring of housing and real estate more generally is the outcome of processes of financialisation or, alternatively, whether financialisation aptly describes a set of technologies and calculative practices that ampify and accelerate existing tendencies of wider neoliberal restructuring of economy, society and of the state itself.

This is unsurprising given housing's central role in state restructuring. The retrenchment of social housing provision and ideological prioritisation of homeownership are core components of neoliberalisation (Madden and Marcuse, 2016). Moreover, the dramatic if variegated expansion of debt-based homeownership - facilitated reciprocally by the expansion and increased interdependence of financial markets - as a dominant housing tenure has been instrumental in configuring new neoliberalised systems of asset-based welfare (Brenner, 2006). The expansion of credit to prop up consumer spending coupled with the growing treatment of housing as an appreciative asset reconfigured the debtproperty relationship and shifted the responsibility of welfare from the state to individualised households (Harvey, 2010). In this sense, housing has been central to the evolution of state neoliberalisation, in driving economic growth through construction, speculation and new rounds of credit through mortgage markets, and in welfare restructuring. All of this suggests a reciprocal and circular relationship between neoliberalisation and financialisation, with the political shifts of the former both necessitating and facilitating the qualitiative transformations and enabling technologies of the latter. However, in broader efforts to explain the GFC, the specific affordances of financialisation and its temporal and geographical differentiation were sometimes too easily subsumed into epochal narratives of neoliberalisation.

The growing interest in the financialisation of housing regimes internationally has, however, been met by a burgeoning and increasingly heterogeneous field of research. On the one hand, housing financialisation is considered in terms of "common trajectories" (Fernandez and Albers 2016) emerging with housing's progressive repositioning from being a key component of state welfare provision to a market-provided model underpinned by private 
homeownership and the expansion of mortgage markets, culminating in the 2008 GFC. While these shifts most pressingly impact access to housing, their reach extends into other areas of neoliberal state restructuring (such as planning, taxation and rental regulation) and, thus, can be associated with variegated neoliberalisation. On the other hand, housing financialisation, particularly its post-GFC iterations, is increasingly examined as a "practical accomplishment" (Fields, 2018): a differentiated phenomenon enacted and embedded in specific contexts and practices via a range of actors operating with differential levels of agency. Working productively across these inter-related strands of analysis, the research on post-GFC housing financialisation has extended the frame of analysis from mortgage markets to include public housing (Aalbers et al, 2017), land (Ward and Swyngedouw, 2018), and investment strategies (van Loon and Aalbers, 2017). This research has sought both to interrogate post-crisis trajectories and strategies of financial actors and to re-examine the co-evolving history of financialisation and neoliberal restructuring. For example, a particular focus has been the intensified 'privatised financialisation' of rental housing, pre-GFC by private equity and hedge funds and extending post-GFC to real estate investment trusts (REITs) and publicly listed real estate firms (Fields and Uffer, 2016). Wijburg et al's (2018) heuristic of rental housing financialisation 1.0 and 2.0 illustrates this pivot. Crucially, such analyses argue that the GFC was not a radical break in housing financialisation, but rather that pre- and post-GFC phases are deeply embedded in the ongoing economic-politicoideological project of neoliberalisation (see Ward and Swyngedouw, 2018; Beswick and Penny 2018). Post-crisis work, therefore, has emphasised how processes and practices of financialisation have been mediated and facilitated by the state in the form of emerging policy and market solutions to problems created by regulatory landscapes already strongly affected by neoliberalisation.

Our agenda here seeks to build on these research trajectories by tracing the embeddedness of financialisation in longer termed and variegated processes of neoliberalisation and unpacking the role of the GFC as a critical historical juncture in both neoliberalisation and intensified financialisation that is enacted in geographically and temporally differentiated ways. As the next section addresses, we seek to shed light on crisis not only as a condition experienced in geographically differentiated ways, but as a discursive (conceptual) framing that mediates understandings of financialisation and shapes its continued temporallydifferentiated evolution. In turning now to 'crisis' itself, we also draw out the value of comparison as an analytical method for teasing out these questions.

\section{The uses of crisis}

The recent ubiquity of crisis - inclusive of the GFC and associated housing crises - has refocused scholarly attention on the concept (Heslop and Ormerod, 2019). While previous theorisations view crisis as signifying a break between historical epochs, Roitman (2013) questions the self-evidence of the category 'crisis' itself. For Roitman, crisis never "obtains", rather it is declared post-hoc as a means to order and make observable a confluence of 
other factors and events: "... crisis is not a condition to be observed ...it is an observation that produces meaning" (p39). Focusing specifically on the GFC, Roitman shows how a range of critical and narrative accounts depend on the mobilisation of a demand to identify systemic error or failure characterised as 'crisis'. Such "crisis-claims" in turn provide the historical hinge to separate the before and after of crisis: "a difference between past and future" (p7). This hinge enables particular forms of critique that attribute past failures and open future possibilities to move beyond them. Roitman insists there is always a gap in the explanatory apparatus - typified by the statements like "housing prices started to fall", "mortage rates began to reset" ( $\mathrm{p44-45)}$ - whereby crisis stands in as a self-referential placeholder in the chain of events:

"Ultimately, the question then arises: when does a credit (asset) become a debt (toxic asset) - how do we demarcate the first form from the second? At what point do houses figured as equity become figured as debt?... Given the creation of an extensive debt market...[or] the widespread practice of debt-financed asset pricing, which [were] pursued over a significant period of time... when and how is it marked as a sign of crisis?" (Roitman, 2013, 48).

For Roitman then, crucially, crisis-claims punctuate what, hitherto, had been a set of normal market conditions.

Deploying the declaration of crisis as a critical and analytical tool, Roitman argues that crisis narratives enable the characterisation of certain elements of markets (such as sub-prime mortgages) as "errors" as opposed to ongoing processes of market making and value creation. Further, she shows how such market making and value creation are enabled through crafting financial techniques and technologies that make financial assets calculative and transferrable (e.g. Murphy, 2019). Significantly for Roitman $(2013,77)$, however, "the postulate of crisis seems to obviate the need for such technical accounts". Drawing on Roitman, our analysis seeks to point out the associations between narrative understandings of crisis as 'error' and specific 'corrective' policy and housing market transformations that have enabled or anticipated the intensification of financialisation across contexts where experiences of the GFC have differed.

Roitman's treatment of 'crisis' also expresses the tensions between understandings of the GFC as the pivotal juncture in the emergence of an epoch of capitalism defined by deepening, expansive and heterogeneous financial practices and logics, and understandings that position financialisation in longer-termed geographically and temporally variegated trajectories of neoliberalising capitalism that straddle the decades before and after 2008. Some recent housing financialisation literature (e.g., Fields, 2018) has worked productively with this tension to tease out the geographically and temporally contingent nature of market making (e.g. of single family homes as a new rental asset class) and situate these transformations within path dependent trajectories of neoliberal state restructuring. Following Roitman, our analysis seeks to highlight where crisis-claims do ambivalent work in 
their capacity to simultaneously mask these more routinised processes of financial reengineering and, simultaneously, open up new spaces for regulatory capture of the state to facilitate further housing market financialisation in specific locales.

Building on this literature, we suggest that comparison can be an important tool in this regard. Here adopt a meso-level analysis (e.g. Peck, 2013) of how the neoliberal policy mechanisms and mobilisations of crisis that undergird and enable the intensification of financialisation are differentially embedded in place, if broadly productive of temporally varied common trajectories. We deploy comparison to foreground the importance of financialisation in longer-term neoliberal housing restructuring while reassessing the GFC in two respects; first, as one important, rather than decisive, moment within longer-term forms of housing restructuring; and, second, as a critical discursive and material juncture where signficant policy and market interventions enable forms of regulatory capture. In the following analysis of Irish and Australian housing systems, we pivot off the GFC to structure our analysis of the longer-term unfolding of housing restructuring in both contexts, while highlighting its role as a juncture in deepening or, alternatively, anticipating housing financialisation.

\section{From welfare to commodity: neoliberalising and financialising housing pre-GFC} In their analysis of varieties of housing financialisation, Fernandez and Albers (2016) group Ireland and Australia in a common trajectory with "high levels of homeownership in combination with high to very high mortgage-to-GDP levels" (p92). Nevertheless, academic and media discussions of both countries' experience with property bubbles prior to and following the GFC has been divergent: Ireland is viewed as a paradigmatic case of financialisation and speculative excess while Australia is viewed as having well regulated banks and therefore relatively non-financialised (Murphy, 2011; O'Riain, 2014). Our aim in this section is to gently disrupt this narrative by positioning the variegated geographies and temporalities of financialisation in both countries in relation to path dependent neoliberal restructuring of housing. This was influenced by four key factors: (i) access to mortgage credit and development capital; (ii) capital switching and investification of housing; (iii) the (neo)liberalisation of planning and taxation regimes; and (iv) the residualisation of social housing. We argue that a common trajectory is evident, nothwithstanding important differences in the position of each country within the global economy and financial markets and in situated policy interventions. These shifts embedded housing financialisation, supported and enabled by neoliberalised state restructuring, particularly during from the 1990s up until the GFC.

\subsection{Ireland}

Ireland's shift from a welfare-based to a marketized model of private homeownership is legible from the 1980s but accelerated markedly during the Celtic Tiger boom 1993-2007 (Kitchin et al, 2012). This involved a number of interdependent factors. As Ireland shifted 
towards a market-based open economy and neoliberal policy regime, membership of the European Union facilitated new flows of credit into the property sector. From the mid1980s, Byrne and Norris, 2019 (pg 2) argue the "private housing market was almost entirely deregulated, liberalized and financialized... as government mortgage provision and subsidies for homeowners were radically reduced; subsidization of the non-profit building societies was ended, and most government controls on capital flows, credit availability and interest rates were removed". These policy reforms were bolstered by the boom from the early 1990s and particularly through Ireland's membership of the European Monetary Union (EMU) and its single currency (1999) which reduced exchange rate risk, facilitated low interest rates and unleashed major bank funding increased through inter-bank lending on a massive scale ( $\mathrm{lbid}$ ). This saw Irish banks importing capital to finance property construction and mortgage credit (O'Riain, 2014). By 2002, the main economic driver shifted from export-led growth through foreign direct investment to a debt-fuelled property bubble. In policy terms, homeownership was prioritised, investment encouraged, and housing markets were viewed a core component of economic growth.

Between 1991 and 2006, 762,541 housing units were built, with 93,419 units built in 2006 alone. Despite this, the average price for new houses increased dramatically by $429 \%$ in Dublin and 382\% nationally (1991 and 2007)' (Kitchin et al, 2016). The shift to debt-based homeownership was lubricated by neoliberal restructuring, as policy switched from social provision to incentivising contruction and homeownership. This was further amplified by the financialisation of home and mortgage markets in the form of a mortgage credit bubble facilitated by the low interest rates that accompanied Ireland's adoption of the Euro (Waldron and Redmond, 2014). The total value of household mortgage debt rose from $€ 47.2 \mathrm{~b}$ to over $€ 139.8 \mathrm{~b}$ 2002-2007, while the average mortgage nearly doubled (Kitchin et al, 2016). The combination of construction and lending bubbles resulted in dramatic increases in the number of mortgaged households (+18\% 2002-2006) and per-capita levels of indebtedness (from $€ 7,000$ to $€ € 33,000,1999-2009)$ (Waldron and Redmond, 2014: 151). The shift to mortgaged homeownership as the dominant tenure was enabled by the relaxation of lending restrictions and the introduction of $100 \%$ and interest-only mortgages.

The more generalised trend of capital switching into property is evident by the parallel expansion of development finance, mortgage finance, and mortgages for second properties. Property consumed the vast bulk of available capital at the expense of other sectors, increasing from $7 \%$ to $28 \%$ of total lending 2000-2007 (O'Riain, 2014). The growing recognition of housing as an investment asset was reflected in first-time buyers gradually being priced out of the market at the expense of household investors. Rapidly rising property prices drove growth in the rental sector, particularly in main urban areas. Indeed, homeownership rates declined from a peak of $81 \%$ in 1991 to $76 \%$ in 2007 (Hearne, 2017). 
These shifts towards housing financialisation were imbricated in and facilitated by ongoing (neo)liberalisation of the planning system and the realignment of tax regimes favourable to debt-based homeownership and property investment (Downey, 2014), including mortgage interest relief as a core pillar of tax policy. The state also introduced a range of tax incentives for urban and rural renewal from 1986, extended nationally up until the GFC (Kitchin et al, 2012). Furthermore, the government rebalanced the burden of tax from income to indirect taxations accruing from the buying and selling of property, rendering stamp duty, capital gains tax and VAT significant contributors to tax. Indeed, such was the shift that the property market accounted for $17 \%$ of total tax revenue in 2006 , up from $5 \%$ in 1998 (Kitchin et al, 2012).

The combination of roll-out neoliberal policies in support of property and the availability of credit resulted in further residualisation and marketisation of social housing. The sector shrank from $31 \%$ of total housing output in the 1960 s to just $10.8 \%$ in the 2000 s. Key to this was the introduction in 2000 of neoliberal planning measures that tied the provision of new social housing to private sector delivery of homes. Additionally, the government introduced a policy of placing social housing tenants in private rental with state subsidy to landlords. By the mid-2000s this had become "an officially sanctioned replacement for [traditional] social housing" (Byrne and Norris, 2019, 9-10). From 1994 to 2006, rent supplement claimants increased by $108 \%$ whereas social housing tenants increased by just $23.6 \%$.

These transformations were the outcome of longer-term neoliberal restructuring, enabled and amplified by financialisation; the flow of development finance and mortgage credit through Ireland's membership of the EMU and the resultant credit bubble that drove a sharp appreciation of house prices and intensified investification. This amplification was geographically and temporally specific; layered onto a pre-existing property boom and related policy tendencies towards globalisation and deregulation set in motion by the first phase of the Celtic Tiger (Kitchin et al, 2012). However, crucially, the extent of housing restructuring during this period was only possible via the assemblage of technologies and practices associated with the financialisation of home and mortgage markets. Cumulatively these shifts amplified the importance of housing to the wider economy, leaving Ireland deeply exposed to the GFC.

\subsection{Australia}

Ireland shared common longterm trajectories with Australia: a growing property bubble underpinned by debt-based homeownership, growing investification of housing and the residualisation of social housing. Nonetheless, exploring these trajectories unearths important differentiations in path dependent neoliberalisation as well as the geographies and temporalities of housing financialisation. 
Australia's longterm status as a homeownership society shifted over the last three decades towards debt-based homeownership. Unlike Ireland's entailment in the EMU, Australia's capacity to set its own fiscal and financial regulatory practices led to a relatively conservative regime of lending standards, full-recourse lending for housing, and limited securitization, imposed by the Australian Prudential Regulatory Authority (APRA). Despite the entrance of non-bank housing lenders from the late 1980s (peaking at $15 \%$ of the mortgage market), the vast majority of housing credit has been provided by the four dominant retail banks (Debelle, 2010) which have been less reliant on international capital to finance construction and mortgage credit (Murphy, 2011). Indeed, the residential property market boom that took hold in Australia from 1996 was underpinned by fundamental demand generated by a booming resource economy (Yates and Milligan, 2007). Australia's state-controlled system of land release and contract method of house construction also curtailed excessive supply compared to Ireland'sii. Yet similar rapid price inflation ensued. Longterm house price escalation (at c.2\% p.a. from the 1970s) shifted in the mid 1990s to rapid uplift (c.7\% p.a., reaching 15\% p.a. in 2001-03), with prices rising faster than incomes since the early 2000s (Murphy, 2011). Between 2001 and 2011, Australian house prices rose by $147 \%$, outstripping household income growth by $90 \%$ (Gurran and Phibbs, 2015). A rapid increase in the demand for mortgage lending ensued, both to owner-occupiers and, crucially, investors, with a steady increase from 1990 until 2007. Over the same period, household indebtedness rose from $45 \%$ of GDP to above $100 \%$ (Heath et al, 2018). By 2007, 86\% of this debt was attributed to mortgages (BIS, 2017). The expansion of mortgage credit grew faster than housing supply which further increased prices, laying the foundations for a housing affordability crisis (Yates, 2011).

As in Ireland, state policy increasingly privileged homeownership and housing investment as an asset class. A first-time buyers grant in 2000 fuelled both homeownership and wider trends of housing's investification (Daley et al. 2018) promoted by easy access to lowinterest mortgage finance and favourable tax treatment of rental investment (Gurran and Phibbs, 2016). Here, again, neoliberal policies, housing system restructuring and state facilitation of financialisation are intertwined. The proportion of bank lending concentrated in the housing sector rose precipitously from $25 \%$ in the early nineties to above $55 \%$ by 2005 (Bullock, 2018). Since deregulation in the mid 1980s, the banking system became increasingly willing to finance loans with 'loan to value' ratios approaching $100 \%$ and to provide higher risk mortgage products (Burke and Hulse, 2010). Importantly however, the expansion of housing credit remained more prudentially regulated than was the case internationally (Murphy, 2011).

Nonetheless, the expansion of mortgage credit and related household indebtedness was stoked by a pro-investment taxation regime. This reflected a shift to asset-based welfare and fashioned households as agents of financialisation, thus amplifying the housing boom (Yates and Milligan, 2007). This regime, underlain by neoliberal logics, exempted the owner- 
occupied 'family home' from capital gains tax (since 1985), state land tax and the agedpension assets test; enabled 'negative gearing' discount on investment properties (1999). As in Ireland, these pro-market measures fostered 'mum and dad' investment in housing and produced a rental sector dominated by smallscale landlords (Martin et al, 2018), at least until the GFC. Rental investors doubled from $15 \%$ to $29 \%$ of the market 1996-2007 (Burke and Hulse, 2010) and loans to investors increased from c. $25 \%$ to c $40 \%$ between the mid 1990 s and 2011 , including via the rapid expansion of interest-only mortgages (Yates 2014). The private rental sector expanded from $18 \%$ to $25 \%$ of total housing stock between 1994/95-2011/12 (AlHW, 2015). All these shifts were enabled by the proliferation of financial technologies and instruments, underwritten by a tax regime that contributed substantially to producing markets in which these techniques could be rolled out.

Other dimensions of neoliberalising housing policy further facilitated housing financialisation. Even as the housing boom was creating deepening difficulties for lowincome households, state-provided social housing and affordable private rental were residualised (Gurran and Phibbs, 2016). Construction of Australia's already modest social housing stock had been contracting since the late 1980s and was further decreased by 'right -to-buy' schemes. Social housing declined from a high of $12 \%$ of total housing output in the mid 1980s to just 3.9\% by 2011/12 (Gurran and Brambley, 2018), failing to keep pace with need since the 1990s. Like Ireland, housing assistance migrated towards the social welfare portfolios, reflecting the growing entrenchment of social housing as an 'exceptional' tenure of last resort and creating market opportunites for subsidised rental and low income housing providers.

Australia's path dependent neoliberal housing restructuring varies from Ireland's in that social housing (and its restructuring) was less significant and macro-prudential regulations on both lending and land release stemmed the bubble economy. Nevertheless, Australia's housing regime was characterised by a similar intersection of state policy facilitating assetbased welfare, nurturing market-making, and the financialisation of home and mortgage markets. Australia's housing market restructuring was driven particularly via a proinvestment taxation regime that shaped households as investor subjects, facilitated capital switching, and escalated a housing boom, albeit within a better regulated and capitalised financial sector. These trends were further entrenched through the 1990s and 2000s.

\section{From GFC to post-crisis housing systems: Continuity and Change}

The GFC forms an important juncture in trajectories of housing financialisation both in Ireland and Australia. Rather than constituting a radical break (cf. Wijburg et al, 2018), the GFC enabled differentiated national policy and market responses that nonetheless, in both contexts, engendered partial continuations of pre-crisis policies and agendas along with 
housing financialisation, if with divergent temporalities. Following Roitman, we suggest below that the observation of the crash as 'crisis' produced differentiated understandings of the GFC, enabling these differentiated responses. In what follows, we analyse post-GFC shifts as the outcome of an interplay between (i) neoliberal path dependencies (a form of regulatory and ideological inertia) and (ii) the geographically and temporally uneven mutation of financialisation practices as crisis claims buoyed the agency of various financial actors (including the state) to capitalise on the crisis and shift more sectors of the housing system towards financialisation.

\subsection{Ireland: intensified financialisation}

The GFC hit Ireland with particular force due to the economy's exposure to inter-bank borrowing, facilitated by EMU membership and the concentration of international capital in property and mortgage lending (O'Riain, 2014). As actors at various scales scrambled to respond to Ireland's financial and property crash (itself embroiled in the wider Eurozone financial crisis), a range of ad hoc policy interventions created conditions for significant market re-engineering. Three key moves defined the Irish Government's response to the GFC: the guarantee of all Irish-owned banks' assets and liabilities; an extensive bank recapitalisation programme; and the establishment of the National Asset Management Agency (NAMA), a 'bad bank' tasked with acquiring largescale real estate loans (above $€ 5 \mathrm{~m}$ ) from five of Ireland's most important banks and their disposal to maximize value ${ }^{\mathrm{iv}}$. This initial response was instrumental in the Government's accepting an IMF-EU-ECB bailout package in late 2010: a move essentially pre-determined by Ireland's position within the EMU (O'Riain, 2014). Here we can note a number of important factors. First, Ireland's EMU membership heavily circumscribed its ability to respond to the GFC ${ }^{v}$. Second, the ad hoc working out of the financial and property crash on the ground reflects Ireland's "commonsense" approach to neoliberalism (Kitchin et al, 2012) while further conditioning the course of housing restructuring. Finally, crisis claims were mobilised by various actors to deepen and transform housing financialisation.

Following the crash, house prices fell by $57.5 \%$ in Dublin and $48.7 \%$ in the rest of the country (CSO, 2015). Unfinished or 'ghost estates' proliferated ${ }^{\text {vi }}$ (Kitchin et al, 2014), while Ireland experienced one of the highest mortgage default rates of any country vii. The stark imprint of residential vacancy and oversupply led to a sudden collapse in development finance. Nonetheless, in line with Ireland's neoliberal path dependency, resolution was largely left to a series of measures that worked with the grain of market forces (Kitchin et al, 2014). Relying on housing market rebound has been the tacit state policy for mitigating the most trenchant aspects of the debt crisis. Nonetheless, new lending restrictions were introduced in 2015 by the Irish Central Bank (a body independent from government) viii. While these were softened following lobbying from the construction and property industry, they significantly curtailed the expansion of mortgage credit (Waldron, 2019). The Irish reponse to the GFC, thereore, involved ad hoc and contested actions of diverse actors within and 
beyond the state. While some specific re-regulation was introduced, the path dependent state reponse opened up other areas of the housing sector to regulatory capture by financialised actors.

One evident impact of this (crisis-talk facilitated) capture is the growing significance of the private rental sector as a tenure and site of investment, aligning with Aalbers' (2015) periodisation of post-crisis housing conditions. While house prices have slowly crept back towards 2006 peaks, private rental expanded to 18.6\% of total households by 2011 (from $8.1 \%$ in 1991) (Byrne and Norris, 2019) and private rents increased by $75 \%$ nationally between 2012 and 2019. A marked acceleration post-crisis has been driven by interlocking factors which property interests - from household investors to international private equity firms - have cultivated and exploited. New mortgage lending restrictions have resulted in higher-earning households spending longer in private rental and the almost complete collapse of construction levels have pushed up average asking rents: in Dublin by $65 \% 2010$ to 2016 (Daft, 2016). More central to our argument here is that the nature of investment in the rental sector has undergone substantial structural transformation, with Dublin particularly becoming "a testbed for financial and property market restructuring" (Waldron 2019) .

These transformations in the property-finance nexus were enacted both through government policy responses to crisis and the related opening up of new housing market opportunities for increasingly influential financial actors. NAMA quickly became the largest player in Dublin's property market (Byrne, 2016) and was instrumental in facilitating the entry of a new set of 'global players', including private equity funds, vulture funds and REITs, especially in Dublin. NAMA explicitly courted institutional investors ${ }^{\mathrm{ix}}$ who, in turn, successfully lobbied for legislation to allow for REITs for the first time (Waldron, 2018). In the post-crash period, Buy-to-Let (BTL) and homeowner lending has contracted significantly, being replaced by large numbers of purchases by landlords with cash/equity, REITs and international property companies. The importance of institutional investors grew substantially: from $3.6 \%$ to $22.5 \%$ of residential property purchases and from $15.5 \%$ and $48 \%$ of residential landlord purchases 2010-2017 (Byrne and Norris 2019, 13). REITs have been particularly influential in shifting the terrain. Ireland's largest private landlord IRES, for example, has acquired disproportional power to set market rents in particular geographical areas. Rising valuations attract more investor interest in REITs and allow them to draw down more debt for further investment, intensifying the cycle of financialisation (Waldron, 2018).

Finally, social housing provision has been further tied to private rental via the state's policy shift towards subsidisation of private landlords for housing social tenants. The Housing Assistance Payment (HAP), which allows claimants to rent private dwellings while rent is paid by the government, was layered onto existing forms of rent supplement in 2014, becoming a pillar of the government's housing strategy (Department of Housing, 2016). 
Funding for social housing fell by $88 \% 2008$-2014 and output contracted dramatically from 7588 to 642 units (Byrne and Norris, 2019), while the number of households receiving HAP increased from 505 in 2005 to 22,020 in 2014 (c7\% of all private-rented tenancies) ${ }^{x}$. The rapid expansion of these subsidies has underpinned the investification of private rental by putting a floor on rents and pushing a growing segment of households into financial market cycles.

Legitimated as crisis-response, the Irish government's ad hoc and pro-market actions have enabled significant transformations in a short time period. These responses have created the conditions for intensified housing financialisation, opened up new sectors of housing to financialisation and, in turn, fuelled severe crises of both affordability and homelessness (Hearne, 2020). Post-crisis restructuring of Ireland's housing regime is thus an intertwined outcome of state policy (which both continued existing neoliberal trajectories and introduced radical measures that facilitated further finacialisation), re-regulation that has created new market opportunities, and financial actors capitalising on crisis conditions to move into new sectors, further restructuring the housing-finance nexus.

\subsection{Australia: protecting a marketized housing regime}

Comparatively, Australia's response to the GFC has not involved such dramatic restructuring of the property-finance nexus. Indeed, the dominant media and academic narrative has been of 'Australian exceptionalism' (Conley, 2018): the absence of a property crash following the GFC-induced credit crunch, resulting both from Australia's relative position with the global economy and financial markets, and from a series of protective post-crisis policy interventions. These interventions also arguably set the conditions for the intensification of housing financialisation, if with a different temporality to Ireland's.

A number of factors protected Australia from GFC contagion. Exposure to risks associated with the US-subprime crash was limited by Australia's strong resource economy, banks' better capitalisation, limited exposure to international borrowing and prudential lending practices. Furthermore, unlike Ireland, the Australian state had autonomy to set fiscal policy responses and these focussed on reasserting the extant houing regime, legitimated as protecting the housing sector from market failures and crisis impacts. In contrast with the pro-cyclical nature of Irish housing policy (Byrne and Norris, 2018), Australian Federal and state governments took counter-cyclical steps post-GFC. Large deposits and wholesale funding guarantees were in place during 2008-2010, but further bank guarantees were unnecessary given careful regulation (Murphy, 2011). Rather, the policy focus fell on boosting construction and reinforcing the system of debt-based homeownership and investification. A two-year \$42b Nation Building Economic Stimulus Plan (NBESP), supported by state-specific programs, stabilised the housing construction industry by funding more than $\$ 6.2 b$ in social housing development (Ruming, 2014) and the simultaneous boosting the first-home buyers grant program causing a spike in lending (Daley et al, 2018). 
Restrictions on foreign investment in property were also temporarily loosened in an effort to ensure prices remained buoyant.

Thus the GFC constituted an important juncture enabling reinforcement of a debt-based and moderately-financialised housing model, notwithstanding increasingly problematic outcomes for affordability (Yates, 2014). Relatedly, the post-crisis period witnessed a continuation of asset price inflation and investification, with residential property investment remaining a lucrative strategy for households due to a largely unchanged regulatory and taxation landscape (Conley, 2018, 50). Financial logics have extended as historically low interest rates fuelled debt-financed investment in private-rental dwellings. Lending to investors increased by $42 \%$ 2006-16 compared to $8.4 \%$ for owners-occupation, while interest-only loans (a hallmark of household investment in rental property) grew to a 2015 peak at $46 \%$ of new mortgages (Heath et al, 2018, Hulse et al, 2018). Notwithstanding APRA's recent intervention that limits debt-to-income ratios, no-interest loans, and caps total lending to property investors ${ }_{L}$ "...financial excesses have built up in the Australian economy... [which connect] Australian households to both domestic and global processes of financialisation" (Conley, 2018, 42). Banks have up to 70\% of their loan-books exposed to the property sector, and the major Australian banks' mortgages equate to $80 \%$ of national GDP (Heath et al, 2018).

Australia's system of development finance and mortgage credit has remained largely unchanged, unlike Ireland's. The financial sector remains concentrated around the four 'big banks' ${ }^{x i}$ who sustained strong profit performance through and beyond the GFC (KPMG, 2017). Indeed, the reassertion of the extant neoliberalised housing system, legitimised by GFC crisis-talk, supported this performance as it sustained house price inflation and demand for mortage credit (RBA, 2017). Prices more than doubled in real terms 1997-2017, notwithstanding the GFC, and after short-term dips ${ }^{x i i}$ Sydney house prices increased $70 \%$ 2012-2017 (Burke, 2018). Consequently, Australian household indebtedness has risen to the highest level among G20 nations at 190\% of disposable income (Heath et al, 2018). Over half of state and local government taxation revenue is property-related via land tax, rates, transaction taxes including stamp duties (CoreLogic, 2016). This position is largely supported by the banking system, which has little reason to seek to unravel the dominant model ${ }^{x i i i}$. Shifting this politico-complex has proven "a diabolical political issue" (Daley et al, 2018), with no government prepared to alienate the interests entailed in an increasingly financialized housing system.

While crisis talk has shored up the neoliberalised housing regime, it has also enabled new policy supports to facilitate the creation of new financialised market opportunities in the private rental and social housing sectors. Private rental has expanded as both a tenure and an investment, belatedly being primed for wider institutional investment. Whereas in Ireland this shift has been buoyed by the introduction of a new set of global players, rental 
investment in Australia has been underpinned initially by the emergence of "generation rent" driven by the growing unaffordability of homeownership (Maalsen, 2018). Private rental grew by $38 \%$ 2006-16, twice the rate of household growth, to reach $26 \%$ of all households and is now the fasted growing sector in the Australian housing system (Hulse et al, 2018). Crucially, recent developments suggest ripening opportunities for larger-scale institutional investment and financialization. While large corporate landlords are still largely absent, with the exception of the off-campus student housing sectors (Pawson et al, 2019), growth in the private rental sector has begun to draw in real estate companies and developers, attracted to yield models such as build-to-rent (BtR). The NSW government established a BtR taskforce in 2017, aiming to build momentum ${ }^{\text {xiv }}$. Thus both contexts are tracking a common trajectory, but enacted through a different set of agents and processes, and unfolding at different temporalities.

Finally, further market opportunities for financial interests are being curated via the continued post-crisis residualisation of social housing. Despite continuously rising demand, between 2008/9 and 2016/17 social housing stock has not kept pace, falling from 5.1 to 4.6 per 100 households between 2007/08 and 2016/17 (AIWH, 2018). Financial techniques are being devised to fund provision both through non-state community housing providers (CHPs) and market-based providers. For instance, a National Housing Finance and Investment Corporation was established in 2017 to act as a 'bond aggregator' to finance for CHPs. This is paralleled by longer-termed transitioning people from social to market housing and by financial innovation via the Social and Affordable Housing Fund, geared to increase private-sector involvement and decrease government "dominance" of the social housing system (NSW Government 2016, 6).

In one sense, the Australian housing system has largely absorbed the 'crisis' substantively unchanged, as the observation of crisis enabled a reassertion of the existing, moderatelyfinancialised housing regime. However, rather than indicating a different trajectory, this suggests a different geographical and temporal relationship mediating the general and specific transformations wrought by the GFC in Australia. The intertwinement of neoliberalising policy stances with financialisation processes continues as nascent conditions for more intenstive financialisation appear on the horizon. Despite rising challenges of affordability, now regularly referred to as a crisis of another kind, little appetite has been shown to introduce measures to reposition the basis of housing provision or to introduce macro-prudential measures that limit the appetite for further house price escalation or further financialisation (Conley, 2018). 


\section{Conclusion}

This paper has aimed to tease out the entanglement of neoliberalisation/financialisation in housing restructuring, situating these processes geographically and temporally and in relation to differential experiences of the GFC. Our comparative approach enables us to trace financialisation's contingent layering onto processes of neoliberalisation, and pinpoint moments wherein financialisation both accelerates and is itself amplified in path dependent trajectories. We draw particular attention to the lubricating role of crisis and 'crisis-talk' in facilitating regulatory restructuring through financialised logics, and the geographical and temporal differentiations that eventuate.

Ireland's and Australia's common trajectories, pre-GFC, are etched in long term state privileging of home-ownership, amplified by a mortgage credit explosion and paralleled by more general capital switching into property. Both countries also residualised social housing, while escalating house prices and household investment readied the private rental sector for amplified institutional investment and related financialisation. While Australia's more prudential regulation of the property-finance nexus cushioned it from the worst impacts of the GFC, Ireland was exposed as particularly vulnerable to the external economic shock of the crash. As governments in each case responded to the declared crisis of the global financial system in divergent yet broadly comparable ways, financialisation's layering across the continuation of modulated versions of ad-hoc neoliberalism is traceable. In Ireland, the crash formed a juncture for regulatory capture by financial actors as crisis discourse facilitated exceptional policy interventions that would radically accelerate and transform housing financialisation. In Australia, a discourse of 'Australian exceptionalism' legitimised policy responses that shored up the existing neoliberalised housing system while also anticipating and facilitating the expansion of financialisation, leaving housing markets vulnerable to its impacts. Despite their differences, the overarching response in both countries has been to reassert broadly neoliberal stances and shore up the hegemony of debt-based home-ownership and its undergirding institutions. Crucially too, encouraged by market actors, each has established alternative avenues and techniques for financialization: in Ireland, for example, amplified by NAMA's operation and in Australia via the construction of markets for rent-yielding assets underpinned by growing demand from 'generation rent'.

These responses do not constitute the GFC as a radical break, yet they reflect the mobilisation of 'crisis' to leverage policy shifts and enable the implanting and diffusion of financial techniques and logics as pre-conditions for deepening housing's financialisation. In Ireland pro-market approach to recovery, alongside more interventionist resurrection of the banking and property sectors enabled the entry of new international financial actors and monopoly interests who have capitalised on the crisis by buying up distressed debt and consolidating their position. In Australia, the stimulus packages propped up the broad debtbased homeownership model and significant moves have been made to nurture the 
creation of markets for residential REITs ${ }^{\mathrm{xv}}$ and other financial vehicles and to leverage their role in the expansion of private rental (Newell et al, 2015). Post-GFC analysis tellingly reveals how crisis is leveraged contingently via key actors, policies and institutions to accomplish further intensification of financialisation and amplify wider processes of housing's neoliberalisation, even as temporalities are distinctive.

At the time of writing, COVID-19 looms: a crisis of another kind with vast potential to enable a step-change in housing's financialisation. Both Ireland and Australia are on the cusp of further housing restructuring, tied to wider recessions. As economic distress ripples outwards, forced sales are likely to eventuate among small-scale housing investors, enabling large-scale institutional investors to gain a foothold, particularly in Australia where hitherto this has not happened. Our comaprative analysis has shown how Australia's moderately financialised system is already primed for this structural transformation. Moreover, as Fields (2018) demonstrates, innovative financial techniques have proliferated to enable the identification, valuing, consolidation and transfer of distressed housing 'assets'; thus lubricating the job of market and regulatory capture through automation. It behoves housing analysts to keep close watch on the moves of financial actors, the extent to which states facilitates new financialisied market opportunities in response to crisis claims, and the role this new crisis plays in articulating with longer termed path dependent trajectories in geographically and temporally-specific contexts.

\section{REFERENCES}

Aalbers MB, 2015, "The great moderation, the great excess and the global housing crisis" International Journal of Housing Policy 15(1) 43-60

Aalbers MB, 2016, The Financialization of Housing: A Political Economy Approach (Routledge, London)

Aalbers, MB, 2017, "Corporate financialization", in The international Encyclopedia of Geography: People, the Earth, Environment, and Technology Eds D Richardson, N Castree, MF Goodchild, AL Kobayashi and R Marston (Wiley, Oxford)

Aalbers MB, 2019a, "Financial geography II: Financial geographies of housing and real estate" Progress in Human Geography 43(2) 376-387

Australian Institute of Health and Welfare, 2015 Housing Assistance in Australia 2015, https://www.aihw.gov.au/reports/housing-assistance/housingassistance-in-australia2015/contents/table-of-contents.

Bullock M, 2018) The Evolution of Household Sector Risks. Speech presented to AI Group https://www.rba.gov.au/speeches/2018/sp-ag-2018-09-10.html

Burke K, 2018 "Sydney house prices record biggest annual drop since global financial crisis" Domain Report https://www.domain.com.au/news/sydney-house-prices-record-biggest-annualdrop-since-global-financial-crisis-domain-report-20180726-h1338x-754186/

Burke T, Hulse K ,2010, "The institutional structure of housing and the sub-prime crisis: Australian case study" Housing Studies, 25(6) 821-838 
Byrne M, 2016, “Asset price urbanism' and financialization after the crisis: Ireland's National Asset Management Agency", International Journal of Urban and Regional Research 40(1) 31-45

Byrne M, Norris M, 2018, "Procyclical social housing and the crisis of Irish housing policy: marketization, social housing, and the property boom and bust" Housing Policy Debate 28(1) 5063

Byrne Norris M, 2019, "Housing market financialization, neoliberalism and everyday retrenchment of social housing M," Environment and Planning A: Economy and Space,

doi.org/10.1177/0308518X19832614

Central Statistics Office, 2015 Residential Property Price Index

http://www.cso.ie/en/releasesandpublications/er/rppi/residentialpropertypriceindexdecember20 $15 /$

Central Bank, 2017 Residential mortgage arrears and repossessions statistics https://www.centralbank.ie/statistics/data-and-analysis/credit-and-bankingstatistics/mortgage-arrears

Conley T, 2018, "The stretched rubber band: banks, houses, debt and vulnerability in Australia" Australian Journal of Political Science 53 (1) 40-56

Corelogic, 2016 Property Taxation Revenue Continues to Rise Media Release, April 28 http://www.macrobusiness.com.au/wpcontent/uploads/2016/04/PropertyPulsePropertyTaxes28April2016-FINAL1.pdf.

Christophers B, 2011 Revisiting the urbanization of capital Annals of the Association of American Geographers 101(6) 1347-1364

Christophers B, 2014 "Geographies of finance I: Historical geographies of the crisis-ridden present" Progress in Human Geography 38 285-293

Christophers B, 2015a "The limits to financialization" Dialogues in human geography 5(2) 183-200 Christophers, B. 2015b "Geographies of finance II: Crisis, space and political-economic transformation: Progress in Human Geography, 39(2), 205-213.

Daft, 2016 The Daft.ie Rental Price Report 2016 http://www.daft.ie/report/2016-q4-rental-daftreport.pdf

Daley J, Coates B, Wiltshire R, 2018 Housing Affordability: Re-imagining the Australian Dream (Grattan Institute, Melbounre)

Downey D, 2014) The financialisation of Irish homeownership and the impact of the global financial crisis in Neoliberal Urban Policy and the Transformation of the City Eds A MacLaran, S Kelly (Springer, Berlin ) pp 120-138

Debelle G, 2010 The State of the Mortgage Market Address to Mortgage Innovation Conference, Sydney, 30 March http://www.rba.gov.au/speeches/2010/sp-ag-300310.html Department of Housing, 2016 Rebuilding Ireland (Government of Ireland, Dublin) Fernandez R, Aalbers MB, 2016, "Financialization and housing: Between globalization and varieties of capitalism" Competition and Change 20(2) 71-88

Fields D, Uffer S, 2016, "The financialisation of rental housing: A comparative analysis of New York City and Berlin" Urban Studies 53(7) 1486-1502

Fields D, 2018, "Constructing a new asset class: property-led financial accumulation after the crisis" Economic Geography 94(2) 118-140

Gurran N, Phibbs, P, 2015, "Are governments really interested in fixing the housing problem? Policy capture and busy work in Australia" Housing Studies 30(5) 711-729

Gurran N, Phibbs, P, 2016, “'Bouvelard of broken dreams': planning, housing supply and affordability in urban Australia" Built Environment 42(1) 55-71 
Gurran N, Bramley G, 2018 Urban Planning and the Housing Market: International Perspectives for Policy and Practice (Palgrave Macmillan, Sydney)

Harvey D, 2010 The Enigma of Capital and the Crises of Capitalism (Profile Books, London)

Hearne R, 2017 A Home or a Wealth Generator? Inequality, Financialization and the Irish Housing Crisis (TASC, Dublin)

Hearne, R (2020) Housing Shock: The Irish Housing Crisis and How to Solve It (Policy Press, Bristol)

Heath M, Cadman E, Dormido, 2018 How Australia's banks became the world's biggest property addicts June 28 https://www.bloomberg.com/graphics/2018-australiaconsumer-debt/

Heslop, J., \& Ormerod, E. (2019). The Politics of Crisis: Deconstructing the Dominant Narratives of the Housing Crisis. Antipode.

Hulse K, Martin C, James A and Stone W, 2018 Private Rental in Trransition: Institutional Change, Technology and Innovation in Australia AHURI Final Report No 296 (AHURI, Melbourne)

Kitchin R, O'Callaghan C, Boyle M, Gleeson J, and Keaveney K, 2012, "Placing neoliberalism: the rise and fall of Ireland's celtic tiger" Environment and Planning A 44(6) 1302-26

Kitchin R, O'Callaghan C, and Gleeson J, 2014, "The new ruins of Ireland? Unfinished estates in the post-celtic tiger era" International Journal of Urban and Regional Research 38(3) 1069-80

Kitchin R, Hearne R, O'Callaghan C, 2016, "Housing" in Austerity and Recovery in Ireland: Europe's Poster Child and the Great Recession Eds William K, Roche PJ, O'Connell and Prothero A, (Oxford University Press, Oxford) pp 272-89

KPMG, 2017 Major Australian Banks: Full Year 2017 Results Analysis https://home.kpmg/content/dam/kpmg/au/pdf/2017/major-australian-banks-full-year2017-results-analysis.pdf

van Loon J, Aalbers MB, 2017, "How real estate became 'just another asset class': The financialization of the investment strategies of Dutch institutional investors" European Planning Studies 25(2) 221-240

Maalsen S, 2018, “'Generation Share': digitalized geographies of shared housing” DOI: $10.1080 / 14649365.2018 .1466355$

Madden D, Marcuse P, 2016 In Defence of Housing (Verso, London)

Murphy L, 2011, "The global financial crisis and the Australian and New Zealand housing markets" Journal of Housing and the Built Environment 26(3), 335-51

Murphy, L. (2019). Performing calculative practices: residual valuation, the residential development process and affordable housing. Housing Studies, 1-17.

Martin C, Hulse K, Pawson H, with Hayden A, Kofner S, Schwartz A, Stephens M, 2017 The Changing Institutions of Private Rental Housing: An International Review Final Report No. 292 (AHURI, Melbourne)

Newell G, Lee C, Kupke V, 2015, The Opportunity of Residential Property Investment Vehicles in Enhancing Affordable Rental Supply, AHURI Positioning Paper No. 166 (AHURI, Melbourne)

O'Riain S, 2014 The Rise and Fall of Ireland's Celtic Tiger: Liberalism, Boom and Bust (Cambridge University Press, Cambridge)

Pawson H, Martin C, van den Nouwelant R, Milligan V, Ruming K, Melo M, 2019, Build to Rent in Australia: Product Feasibility and Affordable Housing Contribution (Landcom, Sydney) 
Peck J, 2010, Constructions of neoliberal reason (OUP, Oxford)

Peck J, 2013, "Explaining (with) neoliberalism" Territory, politics, governance 1(2), 132-157

Reserve Bank of Australia, 2017, Financial Aggregates, June 2017

https://www.rba.gov.au/statistics/ frequency/fin-agg/2017/fin-agg-0617.html

Roitman, J. (2013). Anti-crisis. (Duke University Press, Durham).

Ruming K, 2014 "Social mix discourse and local resistence to social housing: the case of the nation building economic stimulus plan, Australia Urban Policy and Research, 32(2), 163-83

Smith M, 2017 "Westpac's George Frazis says deposits are the obstacle for first home buyers" Australian Financial Review 14 October http://www.afr.com/business/bankingand-finance/westpacs-georgefrazis-says-deposits-are-the-obstacle-for-first-home-buyers20170812-gxux31\#ixzz4qcxpSQY

Stephens M, 2011, "Comparative housing research: a "system-embedded" approach" International Journal of Housing Policy 11(4) 337-355

Waldron R, Redmond D, 2014, The extent of the mortgage crisis in Ireland and policy responses Housing Studies 29(1), 149-165

Waldron R, 2018, "Capitalizing on the state: the political economy of real estate investment trusts and the 'resolution' of the crisis" Geoforum 90 206-218

Waldron R, 2019, "Financialization, urban governance and the planning system: Utilizing 'cevelopment viability'as a policy narrative for the liberalization of Ireland's post-crash planning system, International Journal of Urban and Regional Research 43(4) 685-704

Ward C, Swyngedouw E, 2018, "Neoliberalisation from the ground up: Insurgent capital, regional struggle, and the assetisation of land" Antipode 50(4) 1077-1097

Wijburg G, Aalbers MB, Heeg S, 2018, "The financialisation of rental housing 2.0: Releasing housing into the privatised mainstream of capital accumulation" Antipode 50(4) 1098-1119 Wong A, 2017, "Transnational real estate in Australia: new Chinese diaspora, media representation and urban transformation in Sydney's Chinatown" International Journal of Housing Policy 17(1) 97-119

Yates J, 2011, "Housing in Australia in the 2000s: On the Agenda Too Late?" in Eds Hugo G, Kearns J The Australian Economy in the 2000s (Reserve Bank of Australia, Canberra) Yates J, 2014, "Protecting housing and mortgage markets in times of crisis: a view from Australia" Journal of Housing and the Built Environment 29(2) 316-82 Yates J, Milligan V, 2007, Housing affordability: a 21st century problem, Final Report No. 105 (AHURI, Melbourne)

\footnotetext{
i Second hand homes followed a similar trend, increasing by $555 \%$ and $489 \%$ over the same period.

ii The contract method involves developers acquiring land, obtaining zoning, clearing, subdividing and providing infrastructure before selling to individual builders or households for subsequent construction. This limits speculation and ties production more closely to demand (Burke and Hulse 2010, 827).

iii Negative gearing allows for losses made on investments such as real estate to be deducted from taxable income derived from all other sources.

iv As noted by Waldron $(2018,210)$ "NAMA became a repository for the failed development-finance sector as 11,000 loans secured against 60,000 properties with an initial loan value of $€ 74$ billion were transferred to NAMA at a cost of $€ 32 \mathrm{bn} "$. $\checkmark$ EMU enabled the free flow of capital from European into Irish banks during the boom, but subsequently constrained its ability to respond to the GFC towards financialised measures.

vi 2846 were identified in 2010 (Kitchin et al, 2014).
} 
vii $11 \%$ of principal dwelling mortgages were in arrears as late as March 2016 (Central Bank, 2017).

viii These restricted loan-to-value ratios and applied a 3.5 loan-to-income ratio to all borrowers

ix See Byrne (2016) for an exposition of NAMA's (i) sale of a large volume of loans over a short time frame; (ii) disposal of these assets primarily through large portfolios of loans backed by real estate; (iii) provision of 'vendor finance' and establishing joint ventures; and (iv) promotion the introduction of REITs.

${ }^{x}$ If rent supplement claimants are added, by 2014 almost one-third of all private renting tenancies were receiving government subsidy (Byrne and Norris, 2019, 10).

${ }^{x i}$ The 'big four' banks account for $90 \%$ of the financial system and $25 \%$ of the ASX200.

xii Dips of less than $5 \%$ in 2008/09 and c2\% in 2011/12 were experienced.

xiii The Head of Westpac's Consumer Bank has argued "this whole notion that you want a system where house prices drop is flawed. It is over $\$ 7$ trillion in terms of an asset. If that loses value it will destabilise the economy...This is not about house prices going down, this is about ensuring that those who find it difficult to raise a deposit have avenues into getting into home-ownership" (Smith, 2017).

xiv Thus far, the financial models to accommodate this (e.g. REITs) have largely been confined to commercial property investment.

${ }^{x v}$ No residential REIT is yet available in Australia, despite their flourishing in other property sectors (Wong 2017). 